\title{
Ex vivo expansion of hematopoietic stem cells
}

\author{
XIE JingJing ${ }^{1,2} \&$ ZHANG ChengCheng ${ }^{2 *}$ \\ ${ }^{1}$ Taishan Scholar Immunology Program, Binzhou Medical University, Yantai 264003, China: \\ ${ }^{2}$ Departments of Physiology and Developmental Biology, University of Texas Southwestern Medical Center, Dallas 75390, USA
}

Received January 4, 2015; accepted June 3, 2015; published online August 4, 2015

\begin{abstract}
Ex vivo expansion of hematopoietic stem cells (HSCs) would benefit clinical applications in several aspects, to improve patient survival, utilize cord blood stem cells for adult applications, and selectively propagate stem cell populations after genetic manipulation. In this review we summarize and discuss recent advances in the culture systems of mouse and human HSCs, which include stroma/HSC co-culture, continuous perfusion and fed-batch cultures, and those supplemented with extrinsic ligands, membrane transportable transcription factors, complement components, protein modification enzymes, metabolites, or small molecule chemicals. Some of the expansion systems have been tested in clinical trials. The optimal condition for ex vivo expansion of the primitive and functional human HSCs is still under development. An improved understanding of the mechanisms for HSC cell fate determination and the HSC culture characteristics will guide development of new strategies to overcome difficulties. In the future, development of a combination treatment regimen with agents that enhance self-renewal, block differentiation, and improve homing will be critical. Methods to enhance yields and lower cost during collection and processing should be employed. The employment of an efficient system for ex vivo expansion of HSCs will facilitate the further development of novel strategies for cell and gene therapies including genome editing.
\end{abstract}

ex vivo expansion, hematopoietic stem cells, niche, signal transduction, cord blood, transplantation, SCID-repopulating cell, genome editing, CRISPR/Cas9

Citation: $\quad$ Xie JJ, Zhang CC. Ex vivo expansion of hematopoietic stem cells. Sci China Life Sci, 2015, 58: 839-853, doi: 10.1007/s11427-015-4895-3

\section{Why ex vivo expansion of HSCs}

Hematopoietic stem cells (HSCs) are defined by their abilities to self-renew and to differentiate into all blood cell types [1-6]. HSCs are the source for all the different lineages of hematopoietic cells and immune cells throughout the human lifetime. Historically, the study of HSCs has been closely related to the potential uses of these cells in clinical applications. HSCs form the basis of bone marrow transplantation and are also a promising cell target for gene therapies [7]. HSC transplantation is used to treat patients with hematopoietic malignancies, genetic defects such as sickle cell anemia and thalassemia, autoimmune diseases,

*Corresponding author (email: Alec.Zhang@UTSouthwestern.edu) and certain solid cancers [8].

In addition to self-renewal and differentiation, as evidenced by the ability of a single stem cell to repopulate the whole hematopoietic system of a mouse [3,9], HSCs are subject to regulation by apoptosis and migrate in regulated fashion. The balance among various cell fates-quiescence, self-renewal, differentiation, apoptosis, and migrationdetermines HSC numbers in vitro and in vivo [10]. Extrinsic modulators (including many cytokines, growth factors, and metabolites) and intrinsic regulators (such as certain transcription factors, cell cycle regulators, and chromatin modulators) control HSC fates through numerous signaling pathways [11-17]. The continued study of the regulation of the HSC fates will further our understanding of stem cell biology and provide important insights into HSC-based 
clinical applications.

A major problem in study and applications of HSCs is the extremely low frequency of HSCs in hematopoietic organs. While the attempt to directly derive differentiated hematopoietic cells from other somatic cells is under development, the techniques to produce clonal, multipotent, and transplantable HSCs from somatic cells, pluripotent embryonic stem cells, or induced pluripotent stem cells prove to be challenging $[18,19]$. In both autologous transplant and allogeneic transplant, high doses of HSCs are needed to achieve the rapid and sustained engraftment that is critical to patient survival and recovery [20]. Methods to efficiently culture HSCs would further clinical applications in several ways. For example, patients transplanted with larger numbers of stem cells have a better chance of survival, partially due to their successful escape from the host-versus-graft effect [20,21]. In autologous transplantation, some patients do not have sufficient HSCs or need tumor purging, and thus patient HSCs must be expanded ex vivo. In addition, umbilical cord blood, a promising cell type for transplantation, does not contain enough cells for adult applications [22,23]. The ability to expand HSCs ex vivo would make this enormously important resource useful for adult transplantation. Furthermore, the ability to expand HSCs in culture would greatly boost the development of gene therapy by allowing selection of transducted cells in which the desired gene has been introduced into the appropriate DNA location; this holds the promise for curing a wide variety of human diseases [10]. In particular, the recently developed targeted genome editing techniques including CRISPR/Cas9 technology [24,25] will be greatly benefited by the ability to expand desired manipulated HSCs ex vivo.

\section{Bone marrow niche of HSCs}

The understanding of the extrinsic regulation of HSC fates in vivo may provide insights into culture of HSCs. In 1978, the concept of HSC niche was introduced by Schofield [26]. Since then, mounting evidence indicates that the niche plays a crucial role in quiescence, self-renewal, differentiation, apoptosis, migration, and immune privilege of HSCs [27-29]. Several types of cells that potentially form bone marrow HSC niches have been reported [27-30]. The supportive cells in the niches produce growth factors and extracellular matrix components and provide other intercellular signals that promote self-renewal rather than differentiation of HSCs. In the endosteal HSC niche osteoblasts are the main supportive cell type for maintenance of hematopoiesis [31-35]. The vascular HSC niche is mainly composed of perivascular stromal cells and endothelial cells including reticular cells that express stromal cell derived factor 1 (SDF-1) [36], CD146-expressing subendothelial stromal cells [37], Nestin ${ }^{+}$ mesenchymal stem cells (MSCs) [38], $\mathrm{NG}^{+}$periarteriolar cells [39], and perisinusoidal $\mathrm{LEPR}^{+}$cells $[40,41]$. In addition, macrophages [42,43], megakaryocytes [44,45], the sympathetic nervous system [46], and adipocytes [47] have also been shown to play roles in the HSC niches. Furthermore, regulatory $\mathrm{T}$ cells co-localize with HSCs in the endosteal area of the bone marrow and protect HSCs from immune attack [48]. The clarification of the nature of HSC niche will facilitate to design better strategies for ex vivo expansion of HSCs.

\section{Expansion of mouse HSCs}

Extensive efforts have been made to culture mouse HSCs in two main categories: cytokine cocktail based liquid culture, and stroma/HSC co-culture. The abilities of many cytokines to support hematopoietic progenitors to form colonies in vitro provided important insights into expansion of functional primitive long-term (LT-) HSCs that are measured by in vivo repopulating activity [49]. In the last two decades, a number of secreted/extracellular proteins/chemicals have been demonstrated to support ex vivo expansion of mouse HSCs, including stem cell factor (SCF) [50], thrombopoietin (TPO) [51-53], Notch ligands [54,55], Wnt ligands [56-59], fibroblast growth factor 1 (FGF-1) [60,61], bone morphogenetic proteins (BMPs) [62], Hedgehogs [62-64], prostaglandin E2 (PGE2) [65], interleukin 10 (IL-10) [66], insulin-like growth factor 2 (IGF-2) [67,68], IGF binding protein 2 (IGFBP2) [69,70], several angiopoietin-like proteins (Angptls) [71-74], and pleiotrophin [75]. Conditional derivatives of certain growth factor receptors have also been used to support HSC expansion in culture [76,77]. The introduction of exogenous transcription factors such as homeotic protein HoxB4 can induce dramatic expansion of HSCs [54,56,78-80].

In parallel, the knowledge gained from the co-culture of HSCs with various stromal cell types, including aorta-gonado-mesonephros (AGM), fetal liver, and bone marrow stromal cells, and with endothelial cells and cancer cells has provided important guidance for development of ex vivo expansion strategies in medium with defined factors [67,68,71,81-85]. The Williams lab [83] established stromal cell lines from yolk sac that support the activities of HSCs and hematopoietic progenitors. Moore et al. [81,82] isolated a number of stromal cell lines from mouse fetal liver and AGM, and used them to identify HSC-supportive secreted factors. The Rafii group [85] demonstrated that Notch ligands and IGFBP2 produced by endothelial cells support ex vivo expansion of mouse HSCs. We identified primary mouse fetal liver stromal cells as a novel HSC supportive population $[67,68]$ and also demonstrated that cancer cells are a rich source of HSC-stimulating proteins [69].

Ex vivo expanded HSCs have gained surprising properties in terms of their interaction with the immune system when transplanted back into mouse recipients. We showed 
that ex vivo-expanded mouse HSCs dramatically upregulated the cell surface immune inhibitor programmed death-ligand 1 (PD-L1, also known as B7-H1 or CD274) and efficiently repopulated allogeneic recipient mice by overcoming the major histocompatibility complex barrier [73]. In this study, a 40-fold increase of the allograft ability of $e x$ vivo expanded HSCs was achieved relative to the uncultured control after $8 \mathrm{~d}$ of culture. In addition to the proliferation signal-induced elevation of PD-L1 expression, the increased numbers of functional HSCs also contributed to this enhancement. Our study suggested that extrinsic cues can modulate the immune privilege of HSCs. It also proposed that ex vivo-expanded HSCs may lower the matching requirement for allogeneic transplantation and significantly improve the successful rate of this difficult transplantation [73,86-88]. Consistently, ex vivo expansion of human HSCs increases regulatory $\mathrm{T}$ cell content and decreases the incidence of graft-versus-host disease (GVHD) [89].

\section{Expansion of human HSCs}

Ex vivo expansion of human HSCs that is important for clinical applications is more challenging than the culture expansion of the mouse counterparts. In early 1990s, the identification of SCF [90-95] and other hematopoietic cytokines [96] led to extensive efforts to culture of human hematopoietic progenitors and HSCs in semi-solid culture and in liquid culture [97-102]. HSCs from human bone marrow, mobilized peripheral blood ( $\mathrm{mPB}$ ), and umbilical cord blood (UCB) have been cultured to expand in a large number of studies. Partially due to their sufficient availability for transplantation and limited transduction ability, there are fewer attempts now to ex vivo expand $\mathrm{mPB}$ or bone marrow HSCs, which were frequently tried in liquid culture in 1990s to early 2000s [97-99,101-103]. Indeed, the functional mPB HSCs as measured by repopulating activity, were able to be expanded 6-fold after three weeks of culture [104]. Umbilical cord blood, on the other hand, has more proliferative potential and reduced matching requirement and contains more stem cells and results in lower risk of chronic GVHD than mPB does; therefore, cord blood is an attractive source of HSCs $[100,105,106]$. As a cord blood unit only contains limited numbers of HSCs, it is often not be sufficient for adult transplantation [22,23]. Ex vivo expansion would become a straightforward means to enable cord blood cells to be useful in adult applications [22,106-108].

CD34 and CD133 are popular markers to isolate the primitive cord blood cells as the starting populations for HSC expansion [108]. Immune-deficient mice including the severe combined immunodeficiency (SCID), non-obese diabetic (NOD)/SCID, and NOD/SCID IL2R $\gamma$ (null) (NSG) mice are popular recipients for transplantation analysis that serves as the "gold standard" to evaluate HSC activity (as SCID-repopulating cells, or SRCs) [109-111]. Although numerous conditions have been used for expansion of HSCs in culture [11,12], a mixture of growth factors/cytokines/ chemicals that allows expansion sufficient for clinically applicability has not yet been determined. Below we summarize results from recent attempts to expand human HSCs ex vivo. The culture systems range from stroma/HSC coculture, continuous perfusion and fed-batch systems, and those supplemented with extrinsic ligands, transcription factors, complement components, protein modification enzymes, metabolites, or small molecule chemicals (See below for details, and also see Table 1 at the end of Section 7 with summary of general features and mechanisms of culture system for human cord blood HSCs).

\section{HSC-mesenchymal stromal cell co-culture}

In vivo, various types of niche cells form a three-dimersion microenvironment for HSCs to control their multiple fates including quiescence, self-renewal, differentiation, apoptosis, and migration. However, under most culture conditions, HSCs undergo apoptosis or differentiation but not self-renewal. In co-culture with primitive hematopoietic cells, various stromal cell types including AGMs, fetal liver, and bone marrow stromal cells, endothelial cells, and mesenchymal stem cells (MSCs) promote HSC expansion [67,68,71,81-85,112,113]. MSCs promote expansion through cell-to-cell contact [114] and cytokine production [115]. Exogenous supplementation or forced expression of HSC-supportive factors in MSCs promotes ex vivo expansion of HSCs [116,117]. In a phase I clinical trial [118], a co-culture of HSCs with mesenchymal stromal cells proved to be safe in engraftment and led to an expansion of total nucleated cells and more rapid recovery of neutrophils and platelets than HSCs transplanted without co-culture.

\section{Continuous perfusion and fed-batch systems}

Although long-term culture of HSCs with cytokines usually leads to differentiation, the removal or dilution of differentiated hematopoietic progenies and their secreted inhibitory signals that negatively regulate HSC self-renewal can promote expansion. A continuous perfusion system [119] and, more recently, a fed-batch system [120] designed to reduce the accumulating negative cues during the culture of HSCs significantly enhanced the expansion of functional primitive HSCs. Both of decreasing the concentration of accumulating negative secreted factors and increasing culture volume to maintain a lower cell density benefits HSC expansion. Using this system, a 12-d culture yielded an 11-fold increase of functional repopulating human cord blood HSCs relative to uncultured controls [120]. The perfusion and fed-batch systems thus represent unique and complementary approaches for expansion of HSCs through regulating the feedback signaling on HSC output. 


\subsection{Notch ligands}

The Notch pathway play major roles in lymphopoiesis, and is also involved in the generation, maintenance, and expansion of HSCs [55]. Notch has a positive effect on selfrenewal of HSCs during stressed hematopoiesis but not at steady state [12]. Notch ligands Delta and Jagged support ex vivo expansion of HSCs. It is known that activated Notch is capable of immortalizing mouse hematopoietic progenitors with multi-lineage reconstitution ability, and Notch ligands support ex vivo expansion of mouse HSCs $[12,55]$. The effect of Notch ligands on HSCs is dose-dependent: a lower dose of Delta 1 stimulates expansion of human cord blood HSCs, whereas higher amounts of the same factor induce programmed cell death [55]. This scenario seems to be not uncommon when we read the literature about cytokine regulation of cell fates of HSCs. It was suggested that the Notch signaling only supports the ex vivo expansion of cord blood HSCs but not adult human HSCs [12]. In a phase I clinical trial, transplantation of immobilized Delta-1-expanded $\mathrm{CD}_{3} 4^{+}$human cord blood cells resulted in neutrophil recovery and myeloid engraftment with no signs of GVHD [121].

\subsection{Wnts and glycogen synthase kinase $3 \beta$ (GSK-3 $\beta$ ) inhibitor}

Wnts are secreted lipidated signaling proteins that bind to Frizzled receptors [122]. Wnt signaling is involved in HSC regulation (reviewed in $[59,123]$ ), and Wnt signaling was reported to maintain HSC in a quiescent status in vivo [124]. The effects of Wnt signaling are dosage and context dependent: low Wnt doses result in expansion of HSCs, whereas high doses cause exhaustion [125]. Soluble Wnt proteins, including Wnt3a and Wnt5a, support mouse and human HSC activity as determined by repopulation assays $[57,58]$. It was also reported that ex vivo Wnt5a-treated young LT-HSCs decreased HSC repopulation ability [126]. Pretreatment with a GSK-3 $\beta$ inhibitor, which activates the canonical Wnt downstream effector $\beta$-catenin, promotes engraftment of ex vivo-expanded human HSCs in xenografted mice $[127,128]$.

\subsection{Shh/BMP/TGF- $\beta$}

The inclusion of sonic hedgehog proteins (Shh) in the culture medium of human $\mathrm{CD} 34^{+} \mathrm{CD} 38^{-} \mathrm{Lin}^{-}$cells was shown to be able to enhance cell proliferation and increase the repopulation in NOD/SCID recipient mice [71]. As we mentioned earlier, Trowbridge et al. [128] showed that a GSK-3 inhibitor that can modulate multiple pathways including the Hedgehog signaling enhances HSC repopulation.

Shh-induced hematopoietic stem/progenitor cell (HSPC) expansion appears to be dependent on downstream BMP-4 signaling, because inhibition of BMP-4 abrogated Shh- induced expansion [71]. BMPs are members of the transforming growth factor $\beta$ (TGF- $\beta$ ) superfamily and known to play a critical role in HSC specification during development. BMP signaling negatively regulates the activity of mouse HSCs via control of the endosteal niche [15]. Human HSCs express BMP receptors [72]; the presence of BMP-4 in culture improved the proliferation and maintenance of human HSPCs [62].

A low concentration of TGF- $\beta 2$ stimulates proliferation of C57BL/6 mouse $\mathrm{Lin}^{-} \mathrm{Sca}-{ }^{+} \mathrm{Kit}^{+}$cells $[129,130]$. The Karlsson laboratory's work [131] suggested that several TGF- $\beta$ family ligands induced signaling pathways are intact in mouse HSCs. Pimanda et al. [132] showed the integration of BMP4/Smad signaling in HSC development. The Nakauchi's laboratory [133,134] demonstrated that nonmyelinating Schwann cells produced TGF- $\beta$ is critical for maintenance of HSC hibernation.

\subsection{FGFs}

Bone marrow reconstitution analysis demonstrated that an FGF receptor is expressed on all long-term (LT-) mouse bone marrow HSCs [60]. The supplementation of FGF-1 and FGF-2 in serum-free medium of unfractionated mouse bone marrow cells supports the expansion of repopulating HSCs [60,61,135]. Crcareva et al. [135] further demonstrated that the FGF-1 induced expanded HSCs are an excellent source for retroviral gene delivery. Conditional derivatives of FGF receptor-1 have also been used to support short-term HSC expansion and long-term HSC survival in culture [76]. The roles of the FGF pathway in regulating adult HSCs and embryonic hematopoietic development need further investigation. The results from different starting cell populations and under different culture conditions were not all consistent. Schiedlmeier et al. [136] showed that when purified adult mouse HSCs and ES cell-derived HSCs that ectopically express HoxB4 were treated with the fibroblast growth factor receptor (FGFR) inhibitor SU5402 repopulating activity was enhanced. These results indicate the complex nature of the cross-talk between FGF signaling and other pathways, and suggest that FGF regulates HSC activity indirectly [61].

\subsection{IGF binding protein 2}

IGFBP2 is a member of the IGFBP family that contains at least six circulating proteins binding to IGF-1 and IGF-2 with affinities equal to or greater than those of IGF receptors (IGF-IR, IGF-IIR, and insulin receptor). While IGFBP2 exhibits IGF-dependent inhibitory effects on growth of many types of cells [137], it also displays IGF-independent activities [69,70,138-146]. We identified IGFBP2 from a cancerous cell line as a supportive secreted factor for mouse and human HSCs [69,147]. Concordantly, the Rafii group [85] demonstrated that IGFBP2 is a critical factor secreted by 
endothelial cells that supports ex vivo expansion of mouse HSCs. IGFBP2 may also support the activity of fetal liver HSCs [148]. These results are accordant with the reported role of nephroblastoma overexpressed (CCN3/NOV), an IGFBP domain-containing protein, which supports expansion of human HSCs [149]. Multiple membrane proteins, including cell surface integrins [139,142-144], Frizzle 8, and low-density lipoprotein (LDL) receptor-related protein 6 [150], were shown to mediate the IGF-independent effects of IGFBP2. Interestingly, extrinsic IGFBP2 can also be taken up into the cytosols of oxidative stressed cells [143,145]. IGF-2 is also a mouse HSC growth factor [67,68]; its effect on human HSCs is unknown. In addition, IGF-2 binds to and stimulates self-renewal of human embryonic stem cells [151]. Despite these data, the mechanisms through which IGFBP2 and IGF-2 support HSC expansion are unclear.

\subsection{Angiopoietin-like proteins}

Angptls are a family of highly glycosylated secreted proteins that play important roles in metabolism, inflammation, hematopoiesis, and cancer $[152,153]$. We showed that several Angptls potently stimulate ex vivo expansion of bone marrow HSCs $[67,68,71]$. This result was confirmed by an independent study showing that Angptl3 supports ex vivo expansion of mouse HSCs [154], and GST-Angptl5 stimulates ex vivo expansion of human cord blood SRCs [147]. In the animal models, Angptls are likely components of the niche of mouse fetal liver and adult HSCs $[68,72]$ and that Angptl1 and 2 are essential to HSC development in zebrafish [155]. We recently showed that leukocyte immunoglobulin-like receptor 2 (LILRB2) is a receptor for multiple Angptls, including GST-Angptl5 [74], and demonstrated that a novel motif in the extracellular domain of LILRB2 mediates Angptl effects [156]. Lin et al. [155] demonstrated that, in human $\mathrm{CD} 34^{+}$cells, Angptl 2 induces NOTCH activation via the interaction between LILRB2 and NOTCH, resulting in activation of myc targets.

Because Angptls are large glycosylated proteins that are readily degraded and that form aggregates, these proteins are difficult to express and purify. We developed a serum-free culture system containing defined cytokines and immobilized anti-LILRB2, which supports a 4.9-fold net expansion of repopulating human cord blood HSCs after 10 $\mathrm{d}$ of culture, as determined by NSG transplantation [156]. As immobilized antibodies likely prevent internalization of the ligand LILRB2 (that contains the internalization signal YXXphi [157]), receptor activation is prolonged, and thus the ex vivo expansion of HSCs can be enhanced by the immobilized antibodies. The anti-LILRB2 polyclonal antibodies are more readily expressed and purified and are more stable than Angptls and, importantly, bind and activate LILRB2 with higher efficiency than Angptl2; use of anti-LILRB2 polyclonal antibodies will have advantages in $e x$ vivo HSC expansion systems [156,158].

\subsection{Pleiotrophin}

Pleiotrophin is a neurite outgrowth factor that is secreted by bone marrow sinusoidal endothelial cells [159]. Pleiotrophin improves the survival of mice following myeloablative treatment [160]. Pleiotrophin supports the ex vivo expansion of mouse bone marrow HSCs as determined by competitive repopulating assays and supports ex vivo expansion of human cord blood $\mathrm{CD} 34^{+} \mathrm{CD} 38^{-} \mathrm{Lin}^{-}$cells as determined by in a SCID-repopulation assay [75]. Pleiotrophin activates phosphoinositide 3-kinase (PI3K) signaling in HSCs, and blocking PI3K or Notch signaling inhibits pleiotrophin-mediated HSC expansion of HSCs [75].

\subsection{TAT-HoxB4 and TAT-NF-Ya}

The introduction of exogenous transcription factors such as HoxB4 can dramatically expand HSCs [54,56,78-80]. Retroviral overexpression of the human $H O X B 4$ gene enables dramatic expansion of mouse bone marrow HSCs in culture [79]. A cell-permeable fusion protein TAT-HOXB4 that includes the protein transduction domain of the HIV transactivating protein TAT and HoxB4 expressed by stromal cells in co-culture with human cord blood CD $34^{+}$cells for 2 weeks results in 2.5-fold increase in expansion compared to the uncultured controls [161].

NF-Ya, the regulatory subunit of the transcription factor NF-Y, activates HOXB4 and other genes implicated in the self-renewal and differentiation of HSCs. The inclusion of recombinant TAT-NF-Ya fusion protein in the culture medium of human primary bone marrow cells for 3-9 d results in a 5-10-fold increase of repopulated huCD $45^{+}$cells in transplanted NSG mice [162].

\subsection{Fucosylating enzymes}

An approach to improve the homing and engraftment of human HSCs is to enhance the fucosylation of selectin ligands expressed by these cells. Selectin ligands must be alpha1-3 fucosylated to form glycan determinants such as sialyl Lewis X. Xia et al. [163] showed that insufficient alpha1-3 fucosylation of human cord blood HSPCs led to decreased binding of these cells to E-selectin and P-selectin. The administration of guanosine diphosphate fucose and exogenous alpha1-3 fucosyltransferase VI or VII $[163,164]$ improved the binding of $\mathrm{CD} 34^{+}$cells to selectins. Fucosyltransferase treatment improved homing and the early and long-term engraftment of cord blood $\mathrm{CD}_{3} 4^{+}$cells in the bone marrow of immune deficient mice. These results suggest that alpha1-3 fucosylation of HSCs might be critical to homing and engraftment. In a Phase $1 / 2$ a clinical trial, a 30 min fucosyltransferase-VI (ASC-101) treatment of human cord blood $\mathrm{CD}_{3} 4^{+}$cells in culture improved neutrophil and platelet recovery in engrafted patients [165]. 


\section{Complement component}

It was shown that the complement component $\mathrm{C} 3 \mathrm{a}$ binds to HSPCs and increases chemokine receptor type 4 (CXCR4) incorporation into membrane lipid rafts to enhance HSPC homing and engraftment [166]. A simple priming of one UCB unit with C3a for $15 \mathrm{~min}$ followed by double UCB transplantation was performed in a phase I study [167]. No adverse effects on survival and no infusional toxicities or activation of inflammatory pathways were observed. Engraftment of the $\mathrm{C} 3$ a-treated $\mathrm{UCB}$, however, was not impaired or favored relative to non-C3a-treated UCB [167].

\subsection{CD26/DPPIV inhibitors}

Preclinical studies have demonstrated that the expression of peptidase CD26 (also known as dipeptidylpeptidase IV) on donor cells decreases homing and engraftment. By contrast, the inhibition of CD26 increased homing, engraftment, and competitive repopulation of HSCs [168-170]. Based on these findings, a clinical trial was conducted to test whether a CD26/DPPIV inhibitor, Sitagliptin, enhanced engraftment after UCB transplant in adult patients with hematological malignancies. Systemic administration of CD26 inhibitor in vivo was safe and may enhance engraftment [171,172].

\subsection{Retinoic acid antagonist}

Retinoic acid (RA) is part of an effective treatment for acute promyelocytic leukemia; however, the role of retinoid signaling in stem cell biology is not clear. In the mouse system, the activation of the RA pathway by all-trans retinoic acid supports ex vivo expansion of HSCs [173]. However, when the RA pathway is inhibited by a dominant negative RAR $\alpha$ mouse HSC repopulation is also supported [174]. Diethylaminobenzaldehyde, an inhibitor of aldehyde dehydrogenase, the enzyme that is responsible for RA synthesis, induced a 3.4-fold of increase of repopulating cord blood HSCs after $7 \mathrm{~d}$ of culture, as determined by SCID repopulation assays [175,176]. Together, these results suggest that RA is an important modulator of HSC homeostasis.

\subsection{Copper chelator, TEPA}

It was reported that elevated copper concentrations in HSC culture stimulates differentiation. By contrast, the inclusion of tetra-ethylenepentamine (TEPA), a Cu chelator, inhibits maturation and supports expansion of human HSCs as determined by NOD/SCID transplantation [177,178]. In a phase I/II clinical trial, the transplantation ability of TEPAcultured cord blood cells were tested by co-transplanting with uncultured cord blood cells into patients. The result showed that $90 \%$ of patients engrafted with no severe GVHD and a 90\% 100-d survival. However, neither neu- trophil nor platelet engraftment times were significantly improved [179].

\subsection{Epigenetic modifiers}

Small molecule inhibitors of histone deacetylase (HDAC) and DNA methyltransferase have been shown to support $e x$ vivo expansion of HSCs in multiple studies. The supplementation of human cord blood $\mathrm{CD} 34^{+}$cells in culture with the HDAC inhibitor valproic acid for $7 \mathrm{~d}$ upregulated expression of stemness genes, elevated aldehyde dehydrogenase activity, and stimulated a 36-fold increase of SCIDrepopulating cells [180]. Another HDAC inhibitor chlamydocin also induced expansion of HSCs in culture [181]. G9a and G9a-like protein (GLP) are methyltransferases that dimethylate histone H3 Lys 9 (H3K9me1/2). Both support hematopoietic lineage specification and differentiation. UNC0638, a G9a/GLP small molecular inhibitor, maintains, but does not induce, expansion of HSC activity in culture [182]. DNA methyltransferase inhibitors and HDAC inhibitors have additive effects in expansion of HSCs in culture. For instance, the DNA methyltransferase inhibitor decitabine [5-aza-2'-deoxycytidine (5azaD)] and the HDAC inhibitor trichostatin A together induced greater ability to maintain HSC activity in vitro than individual single agents $[183,184]$. It was suggested that valproic acid and $5 \mathrm{azaD} /$ trichostatin A prevent the loss and support net expansion of HSCs, respectively [185].

\section{5 p38 inhibitor}

The activation of p38 mitogen-activated protein kinase plays a role in HSC senescence [186,187]. A p38 specific inhibitor, SB203580, supports 3-fold of increase of SRCs after human cord blood $\mathrm{CD} 133^{+}$cells were cultured for $7 \mathrm{~d}$, as determined by the NOD/SCID reconstitution analysis. This effect was primarily attributed to the inhibition of HSC senescence as no significant effect on HSC differentiation and proliferation was observed [188].

\subsection{Sirtuin 1 (SIRT1) inhibitor}

Nicotinamide (NAM), a form of vitamin B-3, inhibits differentiation and improves homing by inhibiting SIRT1 deacetylase. Treatment of human cord blood HSCs with NAM enhances repopulation in culture [189]. In a phase I study, CD133 ${ }^{+}$cord blood cells expanded for $21 \mathrm{~d}$ in the presence of NAM and the non-cultured CD133- cells from one UCB unit of cord blood (NiCord) were co-transplanted with an unmanipulated UCB unit into patients with hematologic malignancies. No adverse effects were observed with the infusion of NiCord. NiCord engraftment remained stable in patients, and the patients who received the NAM-treated culture achieved earlier median neutrophil 
Table 1 Summary of preclinical and clinical studies of ex vivo expansion of human cord blood HSCs

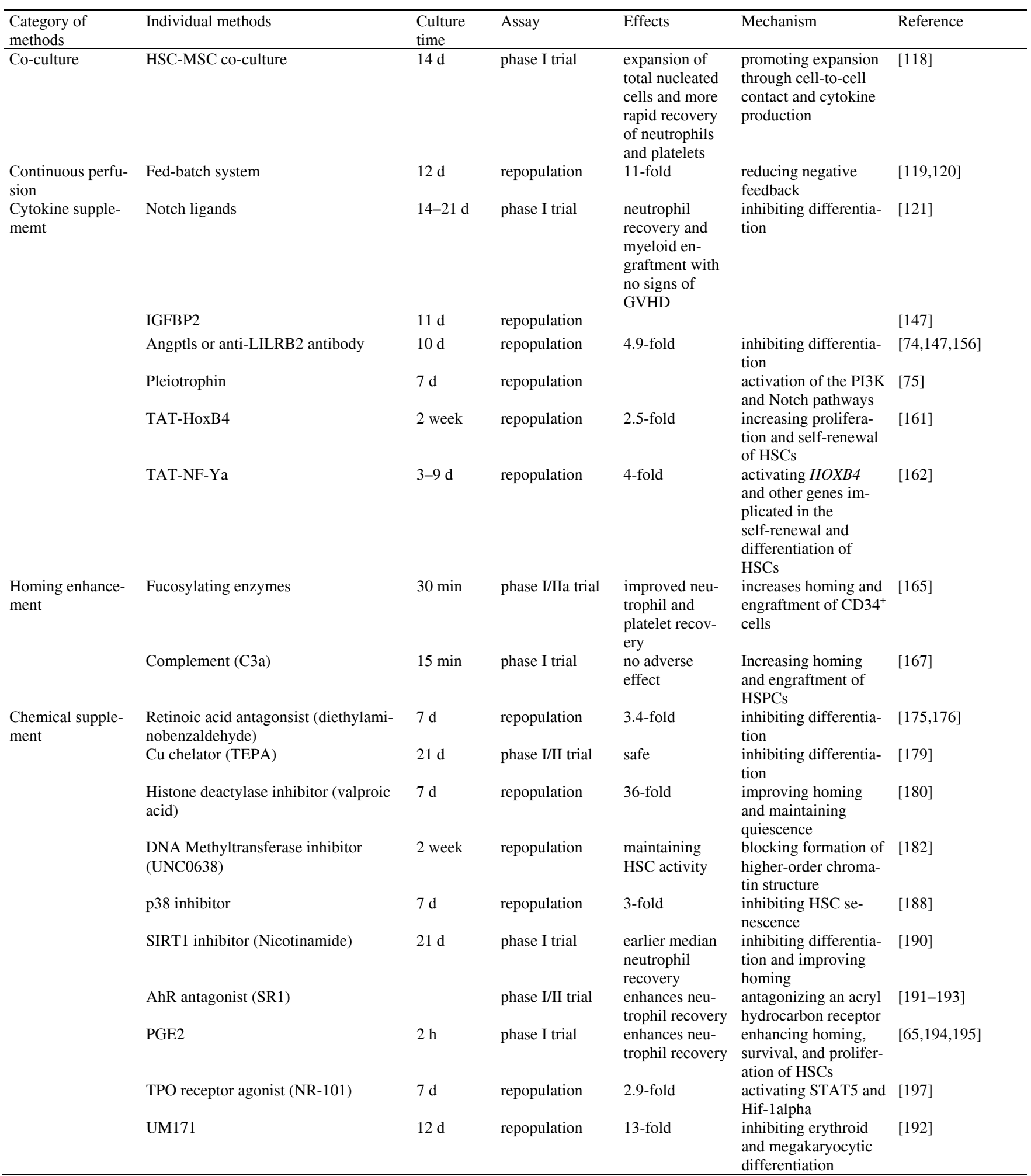

recovery than those given untreated cord blood [190]. EX-527, another SIRT1 inhibitor, also inhibits differentiation of human CD34 ${ }^{+}$cells [189]. The mechanism by which NAM supports engraftment of HSCs should be further investigated.

\subsection{StemRegenin 1 (SR1)}

A purine derivative, StemRegenin 1 (SR1), was identified through a high-throughput screening for the ability to support the ex vivo expansion of $\mathrm{CD} 34^{+}$cells in the presence of cytokines [191]. SR1 increases SRC expansion 17 fold. SRI 
antagonizes an acryl hydrocarbon receptor (AhR), but how this results in support of HSC expansion is unknown. SR1 does not support ex vivo expansion of mouse HSCs or adult human HSCs [182]. Recently, it was suggested that SR1 acts on cells with limited self-renewal potential but that it does not support proliferation of the most primitive HSCs [192]. A phase I/II clinical trial is ongoing and early results indicate that the SR1-containing culture system significantly enhances neutrophil recovery after transplantation [193].

\subsection{Prostaglandin E2 (PGE2)}

A screening of chemicals that induce HSC proliferation in zebrafish led to the identification of prostaglandin E2 (PGE2) as a stem cell-supportive chemical. Short treatment with PGE2 enhanced ex vivo expansion of long-term repopulating mouse HSCs [65] and also supported ex vivo expansion of unfractionated and $\mathrm{CD} 34^{+}$cord blood cells as determined by xenograft experiments [194]. PGE2-treated primate $\mathrm{CD} 34^{+} \mathrm{mPB}$ stem cells exhibit stable multilineage repopulation [194]. A phase I clinical trial with 16,16dimethyl prostaglandin E2-treated cord blood demonstrated safety and accelerated neutrophil recovery in patients receiving this treatment compared to controls [195].

\subsection{Thrombopoietin (TPO) receptor agonist}

TPO signaling maintains quiescence and enhances expansion of HSCs during crisis [196]. As a small molecule agonist of the thrombopoietin (TPO) receptor MPL, NR-101 stimulates ex vivo expansion of human HSCs [197]. A 2.9-fold increase in SRC numbers was observed in NR-101-treated human CD34 ${ }^{+}$cells in a 7-d culture compared to uncultured cells, and a 2.3-fold increase was observed compared to human $\mathrm{CD}_{3} 4^{+}$cells treated with TPO. NR-101 activates signal transducer and activator of transcription 5 (STAT5) but not STAT3, and also induces activities of HIF-1 $\alpha$ and its downstream targets [197].

\subsection{UM171}

The Sauvageau group [192] screened a chemical library for compounds that support ex vivo expansion of $\mathrm{mPB}$ $\mathrm{CD} 34^{+} \mathrm{CD} 45 \mathrm{R}^{-}$cells and identified pyrimidoindole derivatives that do not suppress the AhR pathway. An effective compound, UM171, was identified through further modification. In the Fed-Batch culture system [120], UM171 supports expansion of hematopoietic progenitors and results in a 13-fold expansion of SRCs. UM171 cooperates with SR1, an inhibitor of the AhR pathway, to induce an increase of hematopoietic progenitors in vitro; UM171, but not SR1, supports expansion of LT-HSCs. Like SR1, UM171 does not have mitogenic activity by itself and thus works together with cytokines. UM171 causes a lymphoid-deficient dif- ferentiation pattern in reconstituted mice. Unlike SR1, UM171 inhibits erythroid and megakaryocytic differentiation. The mechanism through which UM171 supports expansion of cord blood LT-HSC expansion and proliferation of adult HSCs or progenitors differs from that of SR1. UM171 is most recently identified compound with HSC stimulatory effects in ex vivo expansion culture.

\section{Summary and perspectives}

The goals of work on ex vivo expansion of HSCs are (i) to make one umbilical cord blood unit sufficient for adult transplantation; (ii) to achieve long-term multi-lineage engraftment, reduce the time of neutrophil and platelet engraftment, and facilitate immune reconstitution; (iii) to improve graft efficiency without causing GVHD; and (iiii) to be cost effective. No ex vivo expansion protocol has yet achieved these goals. A major problem of the current protocols for ex vivo expansion of human HSCs is that there is no convincing evidence that one unit of UCB can be expanded to replace the double units currently required for effective adult transplantation. In some cases, the uncultured UCB unit appears to be responsible for the long-term engraftment. In addition, improved immune reconstitution from expanded UCB units has not been achieved. This may be due to the lack of expansion of primitive human HSCs when existing protocols are used or may result from variation of individual units of cord blood. Moreover, the problem may come from the graft-graft immune reactions of the two transplanted UCB units. To avoid this, the expanded UCB unit may be tried as a sole source for some trials.

Although the optimal condition for ex vivo expansion of HSCs is still under development, a better understanding of the mechanisms involved in HSC cell fate determination and the HSC culture characteristics will guide development of new strategies to overcome difficulties. A unique feature of ex vivo expansion of HSCs is that no single factor supports HSC expansion. This is possibly due to the fact that HSCs can have different fates-self-renewal, differentiation, apoptosis, and migration. During culture, the cell fates of HSCs are often dominated by differentiation or apoptosis. Therefore, although many factors increase the total cell numbers in HSC culture, in most cases, the cultures are overpopulated by mature differentiated cells rather than the desired most primitive stem cells. Therefore our goal should be to identify factors that support self-renewal and to suppress the other possible cell fates. The most important factors in ex vivo expansion of HSCs will thus include factors that inhibit differentiation and apoptosis.

Another interesting observation is that recently identified protein factors and chemicals effective in ex vivo expansion of HSCs are not necessarily typical hematopoietic growth factors or those that activate classical HSC pathways. Some newly identified factors induce developmentally conserved 
pathways or act on nonessential pathways for HSC function, usually through gain-of-function effects. For example, binding of the receptor LILRB2 by the ligand Angptls supports HSC expansion; however, LILRB knockout in mice does not have an overt phenotype in hematopoiesis [74]. The AhR pathway is non-essential during HSC development but appears to be important for ex vivo expansion of HSCs as demonstrated by the effectiveness of the AhR antagonist SR1 [191].

An unresolved question that limits the future development of improved systems for ex vivo expansion of HSCs is why the surface phenotype of cultured HSCs differs so dramatically from that of freshly isolated HSCs. Therefore there is no reliable in vitro measure of the activity of cultured HSCs. It is well aware that the surface phenotypes of mouse and human HSCs are changed upon ex vivo culture $[84,198,199]$. Due to a lack of better markers, $\mathrm{CD} 34^{+} \mathrm{CD} 38^{-} \mathrm{CD} 90^{+} \mathrm{CD} 45 \mathrm{R}^{-} \mathrm{CD} 49 \mathrm{f}^{+}$, the surface phenotype of freshly isolated human HSCs [200] has been used to screen for HSC supportive chemicals in vitro [192]. Better in vitro measures of HSC activity would make screening more effective.

The cost of ex vivo culture of HSCs is relatively high. It is an open question whether we should use enriched or unenriched HSCs as a starting population for ex vivo expansion. Most currently used ex vivo expansion approaches use partially enriched HSCs such as $\mathrm{CD} 34^{+}$cells or CD $133^{+}$ cells. These cells appear to expand more readily than unenriched cells - at least in terms of number increases. Nevertheless, a portion of HSCs present in the original unfrozen cord blood unit may be lost during this fractionation process. Methods to minimize processing or optimize enrichment should be identified.

In the future, work should proceed in several directions to improve the existing systems for ex vivo expansion of HSCs. First, new approaches to enable expansion of the primitive multi-lineage $\mathrm{HSCs}$ - not only the progenitors-are essential. Second, a combination of approaches are necessary to optimally expand HSCs. These might include development of a combination treatment regimen with agents that enhance self-renewal, that block differentiation, and that improve homing. For instance, given the interaction between Notch and Angptl2 receptor in human HSPCs [155], it is reasonable to propose to combine the Notch ligandsand Angptl-based HSC culture systems for further improvement of the ex vivo expansion of primitive cord blood HSCs. In addition, 3D culture and fed-batch culture methods may be pursued, and methods to enhance yields and lower cost during collection and processing should be developed. Furthermore, a cord blood bank would be useful if pre-expanded units were in stock. In this way, sufficient numbers of functional stem cells from the expanded cord blood HSCs can be directly transplanted into matched adult patients. Finally, the application of the targeted genome editing techniques to HSCs can be limited without the ca- pacity of selective expansion of the HSCs in which the desired genomic loci are modified [201]. A combination of techniques in ex vivo expansion and genome editing such as CRISPR/Cas9 technology would enable the further development of HSC-based gene therapy.

We regret that we have been unable to cite many relevant primary references due to space limitations. This work was supported by the National Institutes of Health (1R01CA172268), the Leukemia \& Lymphoma Society (1024-14 and TRP-6024-14), the March of Dimes Foundation (1-FY14-201), the Cancer Prevention and Research Institute of Texas (RP140402), and the Taishan Scholar Program.

1 Till JE, McCulloch CE. A direct measurement of the radiation sensitivity of normal mouse bone marrow cells. Radiat Res, 1961, 14: 213-222

2 Abramson S, Miller RG, Phillips RA. The identification in adult bone marrow of pluripotent and restricted stem cells of the myeloid and lymphoid systems. J Exp Med, 1977, 145: 1567-1579

3 Jordan CT, McKearn JP, Lemischka IR. Cellular and developmental properties of fetal hematopoietic stem cells. Cell, 1990, 61: 953-963

4 Morrison SJ, Uchida N, Weissman IL. The biology of hematopoietic stem cells. Annu Rev Cell Dev Biol, 1995, 11: 35-71

5 Babovic S, Eaves CJ. Hierarchical organization of fetal and adult hematopoietic stem cells. Exp Cell Res, 2014, 329: 185-191

6 Cullen SM, Mayle A, Rossi L, Goodell MA. Hematopoietic stem cell development: an epigenetic journey. Curr Top Dev Biol, 2014, 107: 39-75

7 Weng AP, Ferrando AA, Lee W, Morris JP 4th, Silverman LB, Sanchez-Irizarry C, Blacklow SC, Look AT, Aster JC. Activating mutations of NOTCH1 in human T cell acute lymphoblastic leukemia. Science, 2004, 306: 269-271

8 Bryder D, Rossi DJ, Weissman IL. Hematopoietic stem cells: the paradigmatic tissue-specific stem cell. Am J Pathol, 2006, 169: 338-346

9 Osawa M, Hanada K, Hamada H, Nakauchi H. Long-term lymphohematopoietic reconstitution by a single CD34-low/negative hematopoietic stem cell. Science, 1996, 273: 242-245

10 Domen J, Weissman IL. Self-renewal, differentiation or death: regulation and manipulation of hematopoietic stem cell fate. Mol Med Today, 1999, 5: 201-208

11 Walasek MA, van Os R, de Haan G. Hematopoietic stem cell expansion: challenges and opportunities. Ann N Y Acad Sci, 2012, 1266: 138-150

12 Dahlberg A, Delaney C, Bernstein ID. Ex vivo expansion of human hematopoietic stem and progenitor cells. Blood, 2011, 117: 6083-6090

13 Huang X, Cho S, Spangrude GJ. Hematopoietic stem cells: generation and self-renewal. Cell Death Differ, 2007, 14: 1851-1859

14 Karlsson G, Blank U, Moody JL, Ehinger M, Singbrant S, Deng CX, Karlsson S. Smad4 is critical for self-renewal of hematopoietic stem cells. J Exp Med, 2007, 204: 467-474

15 Ross J, Li L. Recent advances in understanding extrinsic control of hematopoietic stem cell fate. Curr Opin Hematol, 2006, 13: 237-242

16 Bonde J, Hess DA, Nolta JA. Recent advances in hematopoietic stem cell biology. Curr Opin Hematol, 2004, 11: 392-398

17 Nakamura-Ishizu A, Takizawa H, Suda T. The analysis, roles and regulation of quiescence in hematopoietic stem cells. Development, 2014, 141: 4656-4666

18 Daley GQ. Deriving blood stem cells from pluripotent stem cells for research and therapy. Best Pract Res Clin Haematol, 2014, 27: 293-297

19 Riddell J, Gazit R, Garrison BS, Guo G, Saadatpour A, Mandal PK, Ebina W, Volchkov P, Yuan GC, Orkin SH, Rossi DJ. Reprogramming committed murine blood cells to induced hematopoietic stem cells with defined factors. Cell, 2014, 157: 
549-564

20 Uchida N, Tsukamoto A, He D, Friera AM, Scollay R, Weissman IL. High doses of purified stem cells cause early hematopoietic recovery in syngeneic and allogeneic hosts. J Clin Invest, 1998, 101: 961-966

21 Jansen J, Hanks S, Thompson JM, Dugan MJ, Akard LP. Transplantation of hematopoietic stem cells from the peripheral blood. J Cell Mol Med, 2005, 9: 37-50

22 Ballen KK. New trends in umbilical cord blood transplantation. Blood, 2005, 105: 3786-3792

23 Munoz J, Shah N, Rezvani K, et al. Concise review: umbilical cord blood transplantation: past, present, and future. Stem Cells Transl Med, 2014, 3: 1435-1443

24 Cox DB, Platt RJ, Zhang F. Therapeutic genome editing: prospects and challenges. Nat Med, 2015, 21: 121-131

25 Doudna JA, Charpentier E. Genome editing. The new frontier of genome engineering with CRISPR-Cas9. Science, 2014, 346: 1258096

26 Schofield R. The relationship between the spleen colony-forming cell and the haemopoietic stem cell. Blood Cells, 1978, 4: 7-25

27 Mendelson A, Frenette PS. Hematopoietic stem cell niche maintenance during homeostasis and regeneration. Nat Med, 2014, 20: 833-846

28 He N, Zhang L, Cui J, Li Z. Bone marrow vascular niche: home for hematopoietic stem cells. Bone Marrow Res, 2014, 2014: 128436

29 Morrison SJ, Scadden DT. The bone marrow niche for haematopoietic stem cells. Nature, 2014, 505: 327-334

30 Lymperi S, Ferraro F, Scadden DT. The HSC niche concept has turned 31. Has our knowledge matured? Ann N Y Acad Sci, 2010, 1192: $12-18$

31 Zhang J, Niu C, Ye L, Huang H, He X, Tong WG, Ross J, Haug J, Johnson T, Feng JQ, Harris S, Wiedemann LM, Mishina Y, Li L. Identification of the haematopoietic stem cell niche and control of the niche size. Nature, 2003, 425: 836-841

32 Calvi LM, Adams GB, Weibrecht KW, Weber JM, Olson DP, Knight MC, Martin RP, Schipani E, Divieti P, Bringhurst FR, Milner LA, Kronenberg HM, Scadden DT. Osteoblastic cells regulate the haematopoietic stem cell niche. Nature, 2003, 425: 841-846

33 Taichman RS, Emerson SG. The role of osteoblasts in the hematopoietic microenvironment. Stem Cells, 1998, 16: 7-15

34 Adams GB, Alley IR, Chung UI, Chabner KT, Jeanson NT, Lo Celso C, Marsters ES, Chen M, Weinstein LS, Lin CP, Kronenberg HM, Scadden DT. Haematopoietic stem cells depend on $\mathrm{G \alpha}_{\mathrm{s}}$-mediated signalling to engraft bone marrow. Nature, 2009, 459: 103-107

35 Xie Y, Yin T, Wiegraebe W, He XC, Miller D, Stark D, Perko K, Alexander R, Schwartz J, Grindley JC, Park J, Haug JS, Wunderlich JP, Li H, Zhang S, Johnson T, Feldman RA, Li L. Detection of functional haematopoietic stem cell niche using real-time imaging. Nature, 2009, 457: 97-101

36 Sugiyama T, Kohara H, Noda M, Nagasawa T. Maintenance of the hematopoietic stem cell pool by CXCL12-CXCR4 chemokine signaling in bone marrow stromal cell niches. Immunity, 2006, 25 : 977-988

37 Sacchetti B, Funari A, Michienzi S, Di Cesare S, Piersanti S, Saggio I, Tagliafico E, Ferrari S, Robey PG, Riminucci M, Bianco P. Self-renewing osteoprogenitors in bone marrow sinusoids can organize a hematopoietic microenvironment. Cell, 2007, 131: 324-336

38 Mendez-Ferrer S, Michurina TV, Ferraro F, Mazloom AR, Macarthur BD, Lira SA, Scadden DT, Ma'ayan A, Enikolopov GN, Frenette PS. Mesenchymal and haematopoietic stem cells form a unique bone marrow niche. Nature, 2010, 466: 829-834

39 Kunisaki Y, Bruns I, Scheiermann C, Ahmed J, Pinho S, Zhang D, Mizoguchi T, Wei Q, Lucas D, Ito K, Mar JC, Bergman A, Frenette PS. Arteriolar niches maintain haematopoietic stem cell quiescence. Nature, 2013, 502: 637-643

40 Ding L, Saunders TL, Enikolopov G, Morrison SJ. Endothelial and perivascular cells maintain haematopoietic stem cells. Nature, 2012, 481: 457-462

41 Kiel MJ, Yilmaz OH, Iwashita T, Terhorst C, Morrison SJ. SLAM family receptors distinguish hematopoietic stem and progenitor cells and reveal endothelial niches for stem cells. Cell, 2005, 121: 1109-1121

42 Chow A, Lucas D, Hidalgo A, Méndez-Ferrer S, Hashimoto D, Scheiermann C, Battista M, Leboeuf M, Prophete C, van Rooijen N, Tanaka M, Merad M, Frenette PS. Bone marrow CD169 ${ }^{+}$ macrophages promote the retention of hematopoietic stem and progenitor cells in the mesenchymal stem cell niche. J Exp Med, 2011, 208: 261-271

43 Winkler IG, Sims NA, Pettit AR, Barbier V, Nowlan B, Helwani F, Poulton IJ, van Rooijen N, Alexander KA, Raggatt LJ, Lévesque JP. Bone marrow macrophages maintain hematopoietic stem cell (HSC) niches and their depletion mobilizes HSCs. Blood, 2010, 116: 4815-4828

44 Zhao M, Perry JM, Marshall H, Venkatraman A, Qian P, He XC, Ahamed J, Li L. Megakaryocytes maintain homeostatic quiescence and promote post-injury regeneration of hematopoietic stem cells. Nat Med, 2014, 20: 1321-1326

45 Bruns I, Lucas D, Pinho S, Ahmed J, Lambert MP, Kunisaki Y, Scheiermann C, Schiff L, Poncz M, Bergman A, Frenette PS. Megakaryocytes regulate hematopoietic stem cell quiescence through CXCL4 secretion. Nat Med, 2014, 20: 1315-1320

46 Katayama Y, Battista M, Kao WM, Hidalgo A, Peired AJ, Thomas SA, Frenette PS. Signals from the sympathetic nervous system regulate hematopoietic stem cell egress from bone marrow. Cell, 2006, 124: 407-421

47 Naveiras O, Nardi V, Wenzel PL, Hauschka PV, Fahey F, Daley GQ. Bone-marrow adipocytes as negative regulators of the haematopoietic microenvironment. Nature, 2009, 460: 259-263

48 Fujisaki J, Wu J, Carlson AL, Silberstein L, Putheti P, Larocca R, Gao W, Saito TI, Lo Celso C, Tsuyuzaki H, Sato T, Côté D, Sykes M, Strom TB, Scadden DT, Lin CP. In vivo imaging of Treg cells providing immune privilege to the haematopoietic stem-cell niche. Nature, 2011, 474: 216-219

49 Rebel VI, Dragowska W, Eaves CJ, Humphries RK, Lansdorp PM. Amplification of Sca-1+ Lin- WGA+ cells in serum-free cultures containing steel factor, interleukin-6, and erythropoietin with maintenance of cells with long-term in vivo reconstituting potential. Blood, 1994, 83: 128-136

$50 \mathrm{Li}$ CL, Johnson GR. Stem cell factor enhances the survival but not the self-renewal of murine hematopoietic long-term repopulating cells. Blood, 1994, 84: 408-414

51 Sitnicka E, Lin N, Priestley GV, Fox N, Broudy VC, Wolf NS, Kaushansky K. The effect of thrombopoietin on the proliferation and differentiation of murine hematopoietic stem cells. Blood, 1996, 87: 4998-5005

52 Matsunaga T, Kato T, Miyazaki H, Ogawa M. Thrombopoietin promotes the survival of murine hematopoietic long-term reconstituting cells: comparison with the effects of FLT3/FLK-2 ligand and interleukin-6. Blood, 1998, 92: 452-461

53 Yagi M, Ritchie KA, Sitnicka E, Storey C, Roth GJ, Bartelmez S. Sustained ex vivo expansion of hematopoietic stem cells mediated by thrombopoietin. Proc Natl Acad Sci USA, 1999, 96: 8126-8131

54 Varnum-Finney B, Xu L, Brashem-Stein C, Nourigat C, Flowers D, Bakkour S, Pear WS, Bernstein ID. Pluripotent, cytokine-dependent, hematopoietic stem cells are immortalized by constitutive Notch1 signaling. Nat Med, 2000, 6: 1278-1281

55 Chiba S. Notch signaling in stem cell systems. Stem Cells, 2006, 24: 2437-2447

56 Reya T, Duncan AW, Ailles L, Domen J, Scherer DC, Willert K, Hintz L, Nusse R, Weissman IL. A role for Wnt signalling in self-renewal of haematopoietic stem cells. Nature, 2003, 423: $409-414$

57 Willert K, Brown JD, Danenberg E, Duncan AW, Weissman IL, Reya T, Yates JR 3rd, Nusse R. Wnt proteins are lipid-modified and can act as stem cell growth factors. Nature, 2003, 423: 448-452

58 Nemeth MJ, Topol L, Anderson SM, Yang Y, Bodine DM. Wnt5a inhibits canonical Wnt signaling in hematopoietic stem cells and enhances repopulation. Proc Natl Acad Sci USA, 2007, 104: 
$15436-15441$

59 Nemeth MJ, Bodine DM. Regulation of hematopoiesis and the hematopoietic stem cell niche by Wnt signaling pathways. Cell Res, 2007, 17: 746-758

60 de Haan G, Weersing E, Dontje B, van Os R, Bystrykh LV, Vellenga $\mathrm{E}$, Miller G. In vitro generation of long-term repopulating hematopoietic stem cells by fibroblast growth factor-1. Dev Cell, 2003, 4: 241-251

61 Yeoh JS, van Os R, Weersing E, Ausema A, Dontje B, Vellenga E, de Haan G. Fibroblast growth factor-1 and -2 preserve long-term repopulating ability of hematopoietic stem cells in serum-free cultures. Stem Cell, 2006, 24: 1564-1572

62 Bhardwaj G, Murdoch B, Wu D, Baker DP, Williams KP, Chadwick K, Ling LE, Karanu FN, Bhatia M. Sonic hedgehog induces the proliferation of primitive human hematopoietic cells via BMP regulation. Nat Immunol, 2001, 2: 172-180

63 Dyer MA, Farrington SM, Mohn D, Munday JR, Baron MH. Indian hedgehog activates hematopoiesis and vasculogenesis and can respecify prospective neurectodermal cell fate in the mouse embryo. Development, 2001, 128: 1717-1730

64 Baron MH. Molecular regulation of embryonic hematopoiesis and vascular development: a novel pathway. J Hematother Stem Cell Res, 2001, 10: 587-594

65 North TE, Goessling W, Walkley CR, Lengerke C, Kopani KR, Lord AM, Weber GJ, Bowman TV, Jang IH, Grosser T, Fitzgerald GA, Daley GQ, Orkin SH, Zon LI. Prostaglandin E2 regulates vertebrate haematopoietic stem cell homeostasis. Nature, 2007, 447: 1007-1011

66 Kang YJ, Yang SJ, Park G, Cho B, Min CK, Kim TY, Lee JS, Oh IH. A novel function of interleukin-10 promoting self-renewal of hematopoietic stem cells. Stem Cells, 2007, 25: 1814-1822

67 Zhang CC, Lodish HF. Insulin-like growth factor 2 expressed in a novel fetal liver cell population is a growth factor for hematopoietic stem cells. Blood, 2004, 103: 2513-2521

68 Chou S, Lodish HF. Fetal liver hepatic progenitors are supportive stromal cells for hematopoietic stem cells. Proc Natl Acad Sci USA, 2010, 107: 7799-7804

69 Huynh H, Llizuka S, Kaba M, Kirak O, Zheng J, Lodish HF, Zhang CC. IGFBP2 secreted by a tumorigenic cell line supports ex vivo expansion of mouse hematopoietic stem cells. Stem Cells, 2008, 26: 1628-1635

70 Huynh H, Zheng J, Umikawa M, Zhang C, Silvany R, Iizuka S, Holzenberger M, Zhang W, Zhang CC. IGF binding protein 2 supports the survival and cycling of hematopoietic stem cells. Blood, 2011, 118: 3236-3243

71 Zhang CC, Kaba M, Ge G, Xie K, Tong W, Hug C, Lodish HF. Angiopoietin-like proteins stimulate ex vivo expansion of hematopoietic stem cells. Nat Med, 2006, 12: 240-245

72 Zheng J, Huynh H, Umikawa M, Silvany R, Zhang CC. Angiopoietin-like protein 3 supports the activity of hematopoietic stem cells in the bone marrow niche. Blood, 2011, 117: 470-479

73 Zheng J, Umikawa M, Zhang S, Huynh H, Silvany R, Chen BP, Chen L, Zhang CC. Ex vivo expanded hematopoietic stem cells overcome the MHC barrier in allogeneic transplantation. Cell Stem Cell, 2011, 9: 119-130

74 Zheng J, Umikawa M, Cui C, Li J, Chen X, Zhang C, Huynh H, Kang X, Silvany R, Wan X, Ye J, Cantó AP, Chen SH, Wang HY, Ward ES, Zhang CC. Inhibitory receptors bind ANGPTLs and support blood stem cells and leukaemia development. Nature, 2012, 485: 656-660

75 Himburg HA, Muramoto GG, Daher P, Meadows SK, Russell JL, Doan P, Chi JT, Salter AB, Lento WE, Reya T, Chao NJ, Chute JP. Pleiotrophin regulates the expansion and regeneration of hematopoietic stem cells. Nat Med, 2010, 16: 475-482

76 Weinreich MA, Lintmaer I, Wang L, Liggitt HD, Harkey MA, Blau CA. Growth factor receptors as regulators of hematopoiesis. Blood, 2006, 108: 3713-3721

77 Suzuki T, Yokoyama Y, Kumano K, Takanashi M, Kozuma S, Takato T, Nakahata T, Nishikawa M, Sakano S, Kurokawa M, Ogawa S, Chiba S. Highly efficient ex vivo expansion of human hematopoietic stem cells using Delta1-Fc chimeric protein. Stem Cells, 2006, 24: 2456-2465

78 Bunting KD, Galipeau J, Topham D, Benaim E, Sorrentino BP. Effects of retroviral-mediated MDR1 expression on hematopoietic stem cell self-renewal and differentiation in culture. Ann N Y Acad Sci, 1999, 872: 125-140; discussion 140-141

79 Antonchuk J, Sauvageau G, Humphries RK. HOXB4-induced expansion of adult hematopoietic stem cells ex vivo. Cell, 2002, 109: 39-45

80 Krosl J, Austin P, Beslu N, Kroon E, Humphries RK, Sauvageau G. In vitro expansion of hematopoietic stem cells by recombinant TAT-HOXB4 protein. Nat Med, 2003, 9: 1428-1432

81 Moore KA, Ema H, Lemischka IR. In vitro maintenance of highly purified, transplantable hematopoietic stem cells. Blood, 1997, 89: 4337-4347

82 Weisel KC, Gao Y, Shieh JH, Moore MA. Stromal cell lines from the aorta-gonado-mesonephros region are potent supporters of murine and human hematopoiesis. Exp Hematol, 2006, 34: 1505-1516

83 Yoder MC, King B, Hiatt K, Williams DA. Murine embryonic yolk sac cells promote in vitro proliferation of bone marrow high proliferative potential colony-forming cells. Blood, 1995, 86: $1322-1330$

84 Zhang CC, Lodish HF. Murine hematopoietic stem cells change their surface phenotype during ex vivo expansion. Blood, 2005, 105: 4314-4320

85 Butler JM, Nolan DJ, Vertes EL, Varnum-Finney B, Kobayashi H, Hooper AT, Seandel M, Shido K, White IA, Kobayashi M, Witte L, May C, Shawber C, Kimura Y, Kitajewski J, Rosenwaks Z, Bernstein ID, Rafii S. Endothelial cells are essential for the self-renewal and repopulation of Notch-dependent hematopoietic stem cells. Cell Stem Cell, 2010, 6: 251-264

86 Condomines M, Sadelain M. Tolerance induction by allogeneic hematopoietic stem cells. Cell Stem Cell, 2011, 9: 87-88

87 Zheng J, Song C, Zhang CC. A new chapter: hematopoietic stem cells are direct players in immunity. Cell Biosci, 2011, 1: 33

88 Zhang CC. Hematopoietic stem cells: interplay with immunity. Am J Blood Res, 2012, 2: 219-227

89 Fan X, Gay FP, Ong SY, Ang JM, Chu PP, Bari S, Lim TK, Hwang WY. Mesenchymal stromal cell supported umbilical cord blood ex vivo expansion enhances regulatory $\mathrm{T}$ cells and reduces graft versus host disease. Cytotherapy, 2013, 15: 610-619

90 Zsebo KM, Wypych J, McNiece IK, Lu HS, Smith KA, Karkare SB, Sachdev RK, Yuschenkoff VN, Birkett NC, Williams LR, Satyagal VN, Tung WF, Bosselman RA, Mendiaz EA, Langley KE. Identification, purification, and biological characterization of hematopoietic stem cell factor from buffalo rat liver-conditioned medium. Cell, 1990, 63: 195-201

91 Martin FH, Suggs SV, Langley KE, Lu HS, Ting J, Okino KH, Morris CF, McNiece IK, Jacobsen FW, Mendiaz EA, Birkett NC, Smith KA, Johnson M Jo, Parker VP, Flores JC, Patel AC, Fisher EF, Erjavec HO, Herrera CJ, Wypych J, Sachdev RK, Pope JA, Leslie I, Wen DZ, Lin CH, Cupples RL, Zsebo KM. Primary structure and functional expression of rat and human stem cell factor DNAs. Cell, 1990, 63: 203-211

92 Anderson DM, Lyman SD, Baird A, Wignall JM, Eisenman J, Rauch C, March CJ, Boswell HS, Gimpel SD, Cosman D, Williams DE. Molecular cloning of mast cell growth factor, a hematopoietin that is active in both membrane bound and soluble forms. Cell, 1990, 63: 235-243

93 Huang E, Nocka K, Beier DR, Chu TY, Buck J, Lahm HW, Wellner $\mathrm{D}$, Leder $\mathrm{P}$, Besmer $\mathrm{P}$. The hematopoietic growth factor $\mathrm{KL}$ is encoded by the $S l$ locus and is the ligand of the c-kit receptor, the gene product of the $W$ locus. Cell, 1990, 63: 225-233

94 Zsebo KM, Williams DA, Geissler EN, Broudy VC, Martin FH, Atkins HL, Hsu RY, Birkett NC, Okino KH, Murdock DC, Jacobsen FW, Langley KE, Smith KA, Takeish T, Cattanach BM, Galli SJ, Suggs SV. Stem cell factor is encoded at the $S l$ locus of the mouse and is the ligand for the c-kit tyrosine kinase receptor. Cell, 1990, 63: 213-224 
95 Williams DE, Eisenman J, Baird A, Rauch C, Van Ness K, March CJ, Park LS, Martin U, Mochizuki DY, Boswell HS, Burgess GS, Cosman D, Lyman SD. Identification of a ligand for the c-kit proto-oncogene. Cell, 1990, 63: 167-174

96 Sieff CA. Hematopoietic growth factors. J Clin Invest, 1987, 79: 1549-1557

97 Brandt J, Srour EF, van Besien K, Briddell RA, Hoffman R. Cytokine-dependent long-term culture of highly enriched precursors of hematopoietic progenitor cells from human bone marrow. J Clin Invest, 1990, 86: 932-941

98 Brugger W, Mocklin W, Heimfeld S, Berenson RJ, Mertelsmann R, Kanz L. Ex vivo expansion of enriched peripheral blood CD34+ progenitor cells by stem cell factor, interleukin-1 beta (IL-1 beta), IL-6, IL-3, interferon-gamma, and erythropoietin. Blood, 1993, 81: 2579-2584

99 Lansdorp PM, Dragowska W. Long-term erythropoiesis from constant numbers of CD34+ cells in serum-free cultures initiated with highly purified progenitor cells from human bone marrow. J Exp Med, 1992, 175: 1501-1509

100 Broxmeyer HE, Hangoc G, Cooper S, Ribeiro RC, Graves V, Yoder M, Wagner J, Vadhan-Raj S, Benninger L, Rubinstein P, Broun ER. Growth characteristics and expansion of human umbilical cord blood and estimation of its potential for transplantation in adults. Proc Natl Acad Sci USA, 1992, 89: 4109-4113

101 Koller MR, Emerson SG, Palsson BO. Large-scale expansion of human stem and progenitor cells from bone marrow mononuclear cells in continuous perfusion cultures. Blood, 1993, 82: 378-384

102 Petzer AL, Hogge DE, Landsdorp PM, Reid DS, Eaves CJ. Self-renewal of primitive human hematopoietic cells (long-term-culture-initiating cells) in vitro and their expansion in defined medium. Proc Natl Acad Sci USA, 1996, 93: 1470-1474

103 Champlin RE, Schmitz N, Horowitz MM, Chapuis B, Chopra R, Cornelissen JJ, Gale RP, Goldman JM, Loberiza FR Jr, Hertenstein B, Klein JP, Montserrat E, Zhang MJ, Ringdén O, Tomany SC, Rowlings PA, Van Hoef ME, Gratwohl A. Blood stem cells compared with bone marrow as a source of hematopoietic cells for allogeneic transplantation. IBMTR Histocompatibility and Stem Cell Sources Working Committee and the European Group for Blood and Marrow Transplantation (EBMT). Blood, 2000, 95: 3702-3709

104 Gammaitoni L, Bruno S, Sanavio F, Gunetti M, Kollet O, Cavalloni G, Falda M, Fagioli F, Lapidot T, Aglietta M, Piacibello W. Ex vivo expansion of human adult stem cells capable of primary and secondary hemopoietic reconstitution. Exp Hematol, 2003, 31: 261-270

105 Schoemans H, Theunissen K, Maertens J, Boogaerts M, Verfaillie C, Wagner J. Adult umbilical cord blood transplantation: a comprehensive review. Bone Marrow Transplant, 2006, 38: 83-93

106 Brunstein CG, Wagner JE. Umbilical cord blood transplantation and banking. Annu Rev Med, 2006, 57: 403-417

107 Kirouac DC, Zandstra PW. Understanding cellular networks to improve hematopoietic stem cell expansion cultures. Curr Opin Biotechnol, 2006, 17: 538-547

108 Robinson S, Niu T, de Lima M, Ng J, Yang H, McMannis J, Karandish S, Sadeghi T, Fu P, del Angel M, O'Connor S, Champlin R, Shpall E. Ex vivo expansion of umbilical cord blood. Cytotherapy, 2005, 7: 243-250

109 Lapidot T, Pflumio F, Doedens M, Murdoch B, Williams DE, Dick JE. Cytokine stimulation of multilineage hematopoiesis from immature human cells engrafted in SCID mice. Science, 1992, 255: 1137-1141

110 Conneally E, Cashman J, Petzer A, Eaves C. Expansion in vitro of transplantable human cord blood stem cells demonstrated using a quantitative assay of their lympho-myeloid repopulating activity in nonobese diabetic-scid/scid mice. Proc Natl Acad Sci USA, 1997, 94 : 9836-9841

111 Bhatia M, Bonnet D, Kapp U, Wang JC, Murdoch B, Dick JE. Quantitative analysis reveals expansion of human hematopoietic repopulating cells after short-term ex vivo culture. J Exp Med, 1997, 186: 619-624
112 McNiece I, Harrington J, Turney J, Kellner J, Shpall EJ. Ex vivo expansion of cord blood mononuclear cells on mesenchymal stem cells. Cytotherapy, 2004, 6: 311-317

113 Robinson SN, Ng J, Niu T, Yang H, McMannis JD, Karandish S, Kaur I, Fu P, Del Angel M, Messinger R, Flagge F, de Lima M, Decker W, Xing D, Champlin R, Shpall EJ. Superior ex vivo cord blood expansion following co-culture with bone marrow-derived mesenchymal stem cells. Bone Marrow Transplant, 2006, 37: 359-366

114 Wagner W, Roderburg C, Wein F, Diehlmann A, Frankhauser M, Schubert R, Eckstein V, Ho AD. Molecular and secretory profiles of human mesenchymal stromal cells and their abilities to maintain primitive hematopoietic progenitors. Stem Cells, 2007, 25: 2638-2647

115 Flores-Figueroa E, Montesinos JJ, Flores-Guzman P, GutiérrezEspíndola G, Arana-Trejo RM, Castillo-Medina S, Pérez-Cabrera A, Hernández-Estévez E, Arriaga L, Mayani H. Functional analysis of myelodysplastic syndromes-derived mesenchymal stem cells. Leuk Res, 2008, 32: 1407-1416

116 Khoury M, Drake A, Chen Q, Dong D, Leskov I, Fragoso MF, Li Y, Iliopoulou BP, Hwang W, Lodish HF, Chen J. Mesenchymal stem cells secreting angiopoietin-like-5 support efficient expansion of human hematopoietic stem cells without compromising their repopulating potential. Stem Cells Dev, 2011, 20: 1371-1381

117 Ong LM, Fan X, Chu PP, Gay FP, Bari S, Ang JM, Li Z, Chen J, Lim SK, Bunte RM, Hwang WY. Cotransplantation of ex vivo expanded and unexpanded cord blood units in immunodeficient mice using insulin growth factor binding protein-2-augmented mesenchymal cell cocultures. Biol Blood Marrow Transplant, 2012, 18: 674-682

118 de Lima M, McNiece I, Robinson SN, Munsell M, Eapen M, Horowitz M, Alousi A, Saliba R, McMannis JD, Kaur I, Kebriaei P, Parmar S, Popat U, Hosing C, Champlin R, Bollard C, Molldrem JJ, Jones RB, Nieto Y, Andersson BS, Shah N, Oran B, Cooper LJ, Worth L, Qazilbash MH, Korbling M, Rondon G, Ciurea S, Bosque D, Maewal I, Simmons PJ, Shpall EJ. Cord-blood engraftment with ex vivo mesenchymal-cell coculture. N Engl J Med, 2012, 367: 2305-2315

119 Koller MR, Manchel I, Maher RJ, Goltry KL, Armstrong RD, Smith AK. Clinical-scale human umbilical cord blood cell expansion in a novel automated perfusion culture system. Bone Marrow Transplant, 1998, 21: 653-663

120 Csaszar E, Kirouac DC, Yu M, Wang W, Qiao W, Cooke MP, Boitano AE, Ito C, Zandstra PW. Rapid expansion of human hematopoietic stem cells by automated control of inhibitory feedback signaling. Cell Stem Cell, 2012, 10: 218-229

121 Delaney C, Heimfeld S, Brashem-Stein C, Voorhies H, Manger RL, Bernstein ID. Notch-mediated expansion of human cord blood progenitor cells capable of rapid myeloid reconstitution. Nat Med, 2010, 16: 232-236

122 Clevers H, Loh KM, Nusse R. Stem cell signaling. An integral program for tissue renewal and regeneration: Wnt signaling and stem cell control. Science, 2014, 346: 1248012

123 Lento W, Congdon K, Voermans C, Kritzik M, Reya T. Wnt signaling in normal and malignant hematopoiesis. Cold Spring Harb Perspect Biol, 2013, 5: a008011

124 Fleming HE, Janzen V, Lo Celso C, Guo J, Leahy KM, Kronenberg $\mathrm{HM}$, Scadden DT. Wnt signaling in the niche enforces hematopoietic stem cell quiescence and is necessary to preserve self-renewal in vivo. Cell Stem Cell, 2008, 2: 274-283

125 Luis TC, Naber BA, Roozen PP, Brugman MH, de Haas EF, Ghazvini M, Fibbe WE, van Dongen JJ, Fodde R, Staal FJ. Canonical wnt signaling regulates hematopoiesis in a dosage-dependent fashion. Cell Stem Cell, 2011, 9: 345-356

126 Florian MC, Nattamai KJ, Dörr K, Marka G, Uberle B, Vas V, Eckl C, Andrä I, Schiemann M, Oostendorp RA, Scharffetter-Kochanek K, Kestler HA, Zheng Y, Geiger H. A canonical to non-canonical Wnt signalling switch in haematopoietic stem-cell ageing. Nature, 2013, 503: 392-396

127 Ko KH, Holmes T, Palladinetti P, Song E, Nordon R, O’Brien TA, 
Dolnikov A. GSK-3 inhibition promotes engraftment of ex vivo-expanded hematopoietic stem cells and modulates gene expression. Stem Cell, 2011, 29: 108-118

128 Trowbridge JJ, Xenocostas A, Moon RT, Bhatia M. Glycogen synthase kinase-3 is an in vivo regulator of hematopoietic stem cell repopulation. Nat Med, 2006, 12: 89-98

129 Langer JC, Henckaerts E, Orenstein J, Snoeck HW. Quantitative trait analysis reveals transforming growth factor- 2 as a positive regulator of early hematopoietic progenitor and stem cell function. J Exp Med, 2004, 199: 5-14

130 Henckaerts E, Langer JC, Orenstein J, Snoeck HW. The positive regulatory effect of TGF- 2 on primitive murine hemopoietic stem and progenitor cells is dependent on age, genetic background, and serum factors. J Immunol, 2004, 173: 2486-2493

131 Utsugisawa T, Moody JL, Aspling M, Nilsson E, Carlsson L, Karlsson S. A road map toward defining the role of Smad signaling in hematopoietic stem cells. Stem Cells, 2006, 24: 1128-1136

132 Pimanda JE, Donaldson IJ, de Bruijn MF, Kinston S, Knezevic K, Huckle L, Piltz S, Landry JR, Green AR, Tannahill D, Göttgens B. The SCL transcriptional network and BMP signaling pathway interact to regulate RUNX1 activity. Proc Natl Acad Sci USA, 2007, 104: 840-845

133 Yamazaki S, Iwama A, Takayanagi S, Eto K, Ema H, Nakauchi H. TGF- $\beta$ as a candidate bone marrow niche signal to induce hematopoietic stem cell hibernation. Blood, 2009, 113: 1250-1256

134 Yamazaki S, Ema H, Karlsson G, Yamaguchi T, Miyoshi H, Shioda S, Taketo MM, Karlsson S, Iwama A, Nakauchi H. Nonmyelinating Schwann cells maintain hematopoietic stem cell hibernation in the bone marrow niche. Cell, 2011, 147: 1146-1158

135 Crcareva A, Saito T, Kunisato A, Kumano K, Suzuki T, Sakata-Yanagimoto M, Kawazu M, Stojanovic A, Kurokawa M, Ogawa S, Hirai H, Chiba S. Hematopoietic stem cells expanded by fibroblast growth factor-1 are excellent targets for retrovirusmediated gene delivery. Exp Hematol, 2005, 33: 1459-1469

136 Schiedlmeier B, Santos AC, Ribeiro A, Moncaut N, Lesinski D, Auer H, Kornacker K, Ostertag W, Baum C, Mallo M, Klump H. HOXB4's road map to stem cell expansion. Proc Natl Acad Sci USA, 2007, 104: 16952-16957

137 Hoeflich A, Wu M, Mohan S, Föll J, Wanke R, Froehlich T, Arnold GJ, Lahm H, Kolb HJ, Wolf E. Overexpression of insulin-like growth factor-binding protein-2 in transgenic mice reduces postnatal body weight gain. Endocrinology, 1999, 140: 5488-5496

138 Russo VC, Bach LA, Werther GA. Cell membrane association of insulin-like growth factor binding protein-2 (IGFBP-2) in the rat brain olfactory bulb. Prog Growth Factor Res, 1995, 6: 329-336

139 Schutt BS, Langkamp M, Rauschnabel U, Ranke MB, Elmlinger MW Integrin-mediated action of insulin-like growth factor binding protein-2 in tumor cells. J Mol Endocrinol, 2004, 32: 859-868

140 Dunlap SM, Celestino J, Wang H, Jiang R, Holland EC, Fuller GN, Zhang W. Insulin-like growth factor binding protein 2 promotes glioma development and progression. Proc Natl Acad Sci USA, 2007, 104: 11736-11741

141 Wang GK, Hu L, Fuller GN, Zhang W. An interaction between insulin-like growth factor-binding protein 2 (IGFBP2) and integrin $\alpha 5$ is essential for IGFBP2-induced cell mobility. J Biol Chem, 2006, 281: 14085-14091

142 Pereira JJ, Meyer T, Docherty SE, Reid HH, Marshall J, Thompson EW, Rossjohn J, Price JT. Bimolecular interaction of insulin-like growth factor (IGF) binding protein-2 with $\alpha v \beta 3$ negatively modulates IGF-I-mediated migration and tumor growth. Cancer Res, 2004, 64: 977-984

143 Hoeflich A, Reisinger R, Lahm H, Kiess W, Blum WF, Kolb HJ, Weber MM, Wolf E. Insulin-like growth factor-binding protein 2 in tumorigenesis: protector or promoter? Cancer Res, 2001, 61: 8601-8610

144 Moore MG, Wetterau LA, Francis MJ, Peehl DM, Cohen P. Novel stimulatory role for insulin-like growth factor binding protein-2 in prostate cancer cells. Int J Cancer, 2003, 105: 14-19
145 Besnard V, Corroyer S, Trugnan G, Chadelat K, Nabeyrat E, Cazals $\mathrm{V}$, Clement A. Distinct patterns of insulin-like growth factor binding protein (IGFBP)-2 and IGFBP-3 expression in oxidant exposed lung epithelial cells. Biochim Biophys Acta, 2001, 1538: 47-58

146 Chen X, Zheng J, Zou Y, Song C, Hu X, Zhang CC. IGF binding protein 2 is a cell-autonomous factor supporting survival and migration of acute leukemia cells. J Hematol Oncol, 2013, 6: 72

147 Zhang CC, Kaba M, Iizuka S, Huynh H, Lodish HF. Angiopoietin-like 5 and IGFBP2 stimulate ex vivo expansion of human cord blood hematopoietic stem cells as assayed by NOD/SCID transplantation. Blood, 2008, 111: 3415-3423

148 Krosl J, Mamo A, Chagraoui J, Wilhelm BT, Girard S, Louis I, Lessard J, Perreault C, Sauvageau G. A mutant allele of the Swi/Snf member BAF250a determines the pool size of fetal liver hemopoietic stem cell populations. Blood, 2010, 116: 1678-1684

149 Gupta R, Hong D, Iborra F, Sarno S, Enver T. NOV (CCN3) functions as a regulator of human hematopoietic stem or progenitor cells. Science, 2007, 316: 590-593

150 Zhu W, Shiojima I, Ito Y, Li Z, Ikeda H, Yoshida M, Naito AT, Nishi J, Ueno H, Umezawa A, Minamino T, Nagai T, Kikuchi A, Asashima M, Komuro I. IGFBP-4 is an inhibitor of canonical Wnt signalling required for cardiogenesis. Nature, 2008, 454: 345-349

151 Bendall SC, Stewart MH, Menendez P, George D, Vijayaragavan K, Werbowetski-Ogilvie T, Ramos-Mejia V, Rouleau A, Yang J, Bossé M, Lajoie G, Bhatia M. IGF and FGF cooperatively establish the regulatory stem cell niche of pluripotent human cells in vitro. Nature, 2007, 448: 1015-1021

152 Kadomatsu T, Endo M, Miyata K, Oike Y. Diverse roles of ANGPTL2 in physiology and pathophysiology. Trends Endocrinol Metab, 2014, 25: 245-254

153 Santulli G. Angiopoietin-like proteins: a comprehensive look. Front Endocrinol (Lausanne), 2014, 5: 4

154 Farahbakhshian E, Verstegen MM, Visser TP, Kheradmandkia S, Geerts D, Arshad S, Riaz N, Grosveld F, van Til NP, Meijerink JP. Angiopoietin-like protein 3 promotes preservation of stemness during ex vivo expansion of murine hematopoietic stem cells. PLoS One, 2014, 9: e105642

155 Lin MI, Price EN, Boatman S, Hagedorn EJ, Trompouki E, Satishchandran S, Carspecken CW, Uong A, DiBiase A, Yang S, Canver MC, Dahlberg A, Lu Z, Zhang CC, Orkin SH, Bernstein ID, Aster JC, White RM, Zon LI. Angiopoietin-like proteins stimulate HSPC development through interaction with notch receptor signaling. Elife, 2015, 4

156 Deng M, Lu Z, Zheng J, Wan X, Chen X, Hirayasu K, Sun H, Lam Y, Chen L, Wang Q, Song C, Huang N, Gao GF, Jiang Y, Arase H, Zhang CC. A motif in LILRB2 critical for Angpt12 binding and activation. Blood, 2014, 124: 924-935

157 Kozik P, Francis RW, Seaman MN, Robinson MS. A screen for endocytic motifs. Traffic, 2010, 11: 843-855

158 Kubota Y. Unveiling Angpt12, a rising HSC expander. Blood, 2014, 124: 833-834

159 Himburg HA, Harris JR, Ito T, Daher P, Russell JL, Quarmyne M, Doan PL, Helms K, Nakamura M, Fixsen E, Herradon G, Reya T, Chao NJ, Harroch S, Chute JP. Pleiotrophin regulates the retention and self-renewal of hematopoietic stem cells in the bone marrow vascular niche. Cell Rep, 2012, 2: 964-975

160 Himburg HA, Yan X, Doan PL, Quarmyne M, Micewicz E, McBride W, Chao NJ, Slamon DJ, Chute JP. Pleiotrophin mediates hematopoietic regeneration via activation of RAS. J Clin Invest, 2014, 124: 4753-4758

161 Amsellem S, Pflumio F, Bardinet D, Izac B, Charneau P, Romeo PH, Dubart-Kupperschmitt A, Fichelson S. Ex vivo expansion of human hematopoietic stem cells by direct delivery of the HOXB4 homeoprotein. Nat Med, 2003, 9: 1423-1427

162 Domashenko AD, Danet-Desnoyers G, Aron A, Carroll MP, Emerson SG. TAT-mediated transduction of NF-Ya peptide induces the ex vivo proliferation and engraftment potential of human hematopoietic progenitor cells. Blood, 2010, 116: 2676-2683

163 Xia L, McDaniel JM, Yago T, Doeden A, McEver RP. Surface 
fucosylation of human cord blood cells augments binding to $\mathrm{P}$-selectin and E-selectin and enhances engraftment in bone marrow. Blood, 2004, 104: 3091-3096

164 Wan X, Sato H, Miyaji H, McDaniel JM, Wang Y, Kaneko E, Gibson B, Mehta-D'Souza P, Chen Y, Dozmorov M, Miller LP, Goodman J, Sun Z, Xia L. Fucosyltransferase VII improves the function of selectin ligands on cord blood hematopoietic stem cells. Glycobiology, 2013, 23: 1184-1191

165 Popat UR, Oran B, Hosing CM, Kebriaei P, Rezvani Kea. Ex vivo fucosylation of cord blood accelerates neutrophil and platelet engraftment. In: Proceeding of 55th ASH Annual Meeting and Exposition Abstract. New Orleans. Washington: American Society of Hematology, 2013, 691

166 Ratajczak MZ, Reca R, Wysoczynski M, Kucia M, Baran JT, Allendorf DJ, Ratajczak J, Ross GD. Transplantation studies in C3-deficient animals reveal a novel role of the third complement component (C3) in engraftment of bone marrow cells. Leukemia, 2004, 18: 1482-1490

167 Brunstein CG, McKenna DH, DeFor TE, Sumstad D, Paul P, Weisdorf DJ, Ratajczak M, Laughlin MJ, Wagner JE. Complement fragment $3 \mathrm{a}$ priming of umbilical cord blood progenitors: safety profile. Biol Blood Marrow Transplant, 2013, 19: 1474-1479

168 Campbell TB, Hangoc G, Liu Y, Pollok K, Broxmeyer HE. Inhibition of CD26 in human cord blood CD34+ cells enhances their engraftment of nonobese diabetic/severe combined immunodeficiency mice. Stem Cells Dev, 2007, 16: 347-354

169 Christopherson KW, 2nd, Paganessi LA, Napier S, Porecha NK. $\mathrm{CD} 26$ inhibition on $\mathrm{CD} 4^{+}$or lineage ${ }^{-}$human umbilical cord blood donor hematopoietic stem cells/hematopoietic progenitor cells improves long-term engraftment into NOD/SCID/Beta $2^{\text {null }}$ immunodeficient mice. Stem Cells Dev, 2007, 16: 355-360

170 Christopherson KW 2nd, Hangoc G, Mantel CR, Broxmeyer HE. Modulation of hematopoietic stem cell homing and engraftment by CD26. Science, 2004, 305: 1000-1003

171 Velez de Mendizabal N, Strother RM, Farag SS, Broxmeyer HE, Messina-Graham S, Chitnis SD, Bies RR. Modelling the sitagliptin effect on dipeptidyl peptidase-4 activity in adults with haematological malignancies after umbilical cord blood haematopoietic cell transplantation. Clin Pharmacokinet, 2014, 53: 247-259

172 Farag SS, Srivastava S, Messina-Graham S, Schwartz J, Robertson MJ, Abonour R, Cornetta K, Wood L, Secrest A, Strother RM, Jones $\mathrm{DR}$, Broxmeyer HE. In vivo DPP-4 inhibition to enhance engraftment of single-unit cord blood transplants in adults with hematological malignancies. Stem Cells Dev, 2013, 22: 1007-1015

173 Purton LE, Bernstein ID, Collins SJ. All-trans retinoic acid enhances the long-term repopulating activity of cultured hematopoietic stem cells. Blood, 2000, 95: 470-477

174 Tsai S, Bartelmez S, Sitnicka E, Collins S. Lymphohematopoietic progenitors immortalized by a retroviral vector harboring a dominant-negative retinoic acid receptor can recapitulate lymphoid, myeloid, and erythroid development. Genes Dev, 1994, 8: 2831-2841

175 Chute JP, Muramoto GG, Whitesides J, Colvin M, Safi R, Chao NJ, McDonnell DP. Inhibition of aldehyde dehydrogenase and retinoid signaling induces the expansion of human hematopoietic stem cells. Proc Natl Acad Sci USA, 2006, 103: 11707-11712

176 Ghiaur G, Yegnasubramanian S, Perkins B, Gucwa JL, Gerber JM, Jones RJ. Regulation of human hematopoietic stem cell self-renewal by the microenvironment's control of retinoic acid signaling. Proc Natl Acad Sci USA, 2013, 110: 16121-16126

177 Peled T, Landau E, Mandel J, Glukhman E, Goudsmid NR, Nagler A, Fibach E. Linear polyamine copper chelator tetraethylenepentamine augments long-term ex vivo expansion of cord blood-derived CD34+ cells and increases their engraftment potential in NOD/SCID mice. Exp Hematol, 2004, 32: 547-555

178 Peled T, Glukhman E, Hasson N, Adi S, Assor H, Yudin D, Landor C, Mandel J, Landau E, Prus E, Nagler A, Fibach E. Chelatable cellular copper modulates differentiation and self-renewal of cord blood-derived hematopoietic progenitor cells. Exp Hematol, 2005, 33:
1092-1100

179 de Lima M, McMannis J, Gee A, Komanduri K, Couriel D, Andersson BS, Hosing C, Khouri I, Jones R, Champlin R, Karandish S, Sadeghi T, Peled T, Grynspan F, Daniely Y, Nagler A, Shpall EJ. Transplantation of ex vivo expanded cord blood cells using the copper chelator tetraethylenepentamine: a phase I/II clinical trial. Bone Marrow Transplant, 2008, 41: 771-778

180 Chaurasia P, Gajzer DC, Schaniel C, D'Souza S, Hoffman R. Epigenetic reprogramming induces the expansion of cord blood stem cells. J Clin Invest, 2014, 124: 2378-2395

181 Young JC, Wu S, Hansteen G, Du C, Sambucetti L, Remiszewski S, O'Farrell AM, Hill B, Lavau C, Murray LJ. Inhibitors of histone deacetylases promote hematopoietic stem cell self-renewal. Cytotherapy, 2004, 6: 328-336

182 Chen X, Skutt-Kakaria K, Davison J, Ou YL, Choi E, Malik P, Loeb K, Wood B, Georges G, Torok-Storb B, Paddison PJ. G9a/GLP-dependent histone H3K9me2 patterning during human hematopoietic stem cell lineage commitment. Genes Dev, 2012, 26 : 2499-2511

183 Araki H, Yoshinaga K, Boccuni P, Zhao Y, Hoffman R, Mahmud N. Chromatin-modifying agents permit human hematopoietic stem cells to undergo multiple cell divisions while retaining their repopulating potential. Blood, 2007, 109: 3570-3578

184 Milhem M, Mahmud N, Lavelle D, Araki H, DeSimone J, Saunthararajah Y, Hoffman R. Modification of hematopoietic stem cell fate by 5aza 2' deoxycytidine and trichostatin A. Blood, 2004, 103: 4102-4110

185 Mahmud N, Petro B, Baluchamy S, Li X, Taioli S, Lavelle D, Quigley JG, Suphangul M, Araki H. Differential effects of epigenetic modifiers on the expansion and maintenance of human cord blood stem/progenitor cells. Biol Blood Marrow Transplant, 2014, 20: 480-489

186 Iiyama M, Kakihana K, Kurosu T, Miura O. Reactive oxygen species generated by hematopoietic cytokines play roles in activation of receptor-mediated signaling and in cell cycle progression. Cell Signal, 2006, 18: 174-182

187 Miyamoto K, Araki KY, Naka K, Arai F, Takubo K, Yamazaki S, Matsuoka S, Miyamoto T, Ito K, Ohmura M, Chen C, Hosokawa K, Nakauchi H, Nakayama K, Nakayama KI, Harada M, Motoyama N, Suda T, Hirao A. Foxo3a is essential for maintenance of the hematopoietic stem cell pool. Cell Stem Cell, 2007, 1: 101-112

188 Zou J, Zou P, Wang J, Li L, Wang Y, Zhou D, Liu L. Inhibition of p38 MAPK activity promotes ex vivo expansion of human cord blood hematopoietic stem cells. Ann Hematol, 2012, 91: 813-823

189 Peled T, Shoham H, Aschengrau D, Yackoubov D, Frei G, Rosenheimer G N, Lerrer B, Cohen HY, Nagler A, Fibach E, Peled A. Nicotinamide, a SIRT1 inhibitor, inhibits differentiation and facilitates expansion of hematopoietic progenitor cells with enhanced bone marrow homing and engraftment. Exp Hematol, 2012, 40: 342-355

190 Horwitz ME, Chao NJ, Rizzieri DA, Long GD, Sullivan KM, Gasparetto C, Chute JP, Morris A, McDonald C, Waters-Pick B, Stiff P, Wease S, Peled A, Snyder D, Cohen EG, Shoham H, Landau E, Friend E, Peleg I, Aschengrau D, Yackoubov D, Kurtzberg J, Peled T. Umbilical cord blood expansion with nicotinamide provides long-term multilineage engraftment. J Clin Invest, 2014, 124: 3121-3128

191 Boitano AE, Wang J, Romeo R, Bouchez LC, Parker AE, Sutton SE, Walker JR, Flaveny CA, Perdew GH, Denison MS, Schultz PG, Cooke MP. Aryl hydrocarbon receptor antagonists promote the expansion of human hematopoietic stem cells. Science, 2010, 329: 1345-1348

192 Fares I, Chagraoui J, Gareau Y, Gingras S, Ruel R, Mayotte N, Csaszar E, Knapp DJ, Miller P, Ngom M, Imren S, Roy DC, Watts KL, Kiem HP, Herrington R, Iscove NN, Humphries RK, Eaves CJ, Cohen S, Marinier A, Zandstra PW, Sauvageau G. Cord blood expansion. Pyrimidoindole derivatives are agonists of human hematopoietic stem cell self-renewal. Science, 2014, 345: 1509-1512 
193 Wagner JE, Brunstein C, McKenna D, Sumstad D, Maahs S, Laughlin M, Perry MS, Boitano AE, Cooke MP, Bleul CC. StemRegenin-1 (SR1) Expansion Culture Abrogates the Engraftment Barrier Associated with Umbilical Cord Blood Transplantation (UCBT). 56th ASH Annual Meeting and Exposition Abstract. San Francisco. Washington: American Society of Hematology, 2014, 728

194 Goessling W, Allen RS, Guan X, Jin P, Uchida N, Dovey M, Harris JM, Metzger ME, Bonifacino AC, Stroncek D, Stegner J, Armant M, Schlaeger T, Tisdale JF, Zon LI, Donahue RE, North TE. Prostaglandin E2 enhances human cord blood stem cell xenotransplants and shows long-term safety in preclinical nonhuman primate transplant models. Cell Stem Cell, 2011, 8: 445-458

195 Cutler C, Multani P, Robbins D, Kim HT, Le T, Hoggatt J, Pelus LM, Desponts C, Chen YB, Rezner B, Armand P, Koreth J, Glotzbecker B, Ho VT, Alyea E, Isom M, Kao G, Armant M, Silberstein L, Hu P, Soiffer RJ, Scadden DT, Ritz J, Goessling W, North TE, Mendlein J, Ballen K, Zon LI, Antin JH, Shoemaker DD. Prostaglandinmodulated umbilical cord blood hematopoietic stem cell transplantation. Blood, 2013, 122: 3074-3081

196 de Graaf CA, Metcalf D. Thrombopoietin and hematopoietic stem cells. Cell Cycle, 2011, 10: 1582-1589
197 Nishino T, Miyaji K, Ishiwata N, Arai K, Yui M, Asai Y, Nakauchi H, Iwama A. Ex vivo expansion of human hematopoietic stem cells by a small-molecule agonist of c-MPL. Exp Hematol, 2009, 37: 1364-1377

198 Noda S, Horiguchi K, Ichikawa H, Miyoshi H. Repopulating activity of ex vivo-expanded murine hematopoietic stem cells resides in the $\mathrm{CD} 48^{-} \mathrm{c}-\mathrm{Kit}^{+} \mathrm{Sca}-1^{+}$lineage marker ${ }^{-}$cell population. Stem Cells, 2008 , 26: 646-655

199 Dorrell C, Gan OI, Pereira DS, Hawley RG, Dick JE. Expansion of human cord blood $\mathrm{CD} 34^{+} \mathrm{CD} 38^{-}$cells in ex vivo culture during retroviral transduction without a corresponding increase in SCID repopulating cell (SRC) frequency: dissociation of SRC phenotype and function. Blood, 2000, 95: 102-110

200 Notta F, Doulatov S, Laurenti E, Poeppl A, Jurisica I, Dick JE. Isolation of single human hematopoietic stem cells capable of long-term multilineage engraftment. Science, 2011, 333: 218-221

201 Genovese P, Schiroli G, Escobar G, Di Tomaso T, Firrito C, Calabria A, Moi D, Mazzieri R, Bonini C, Holmes MC, Gregory PD, van der Burg M, Gentner B, Montini E, Lombardo A, Naldini L. Targeted genome editing in human repopulating haematopoietic stem cells. Nature, 2014, 510: 235-240

Open Access This article is distributed under the terms of the Creative Commons Attribution License which permits any use, distribution, and reproduction in any medium, provided the original author(s) and source are credited. 